\title{
Acetylation at lysine 346 controls the transforming activity of the HTLV-1 Tax oncoprotein in the Rat-1 fibroblast model
}

\author{
Julie Lodewick', Carla Sampaio ${ }^{1,3}$, Mathieu Boxus ${ }^{2}$, Anne-Sophie Rinaldi ${ }^{1}$, Katia Coulonval ${ }^{3}$, Luc Willems ${ }^{2}$,
} Pierre P Roger ${ }^{3}$ and Françoise Bex ${ }^{1 *}$

\begin{abstract}
Background: Transformation by the Tax oncoprotein of the human T cell leukemia virus type 1 (HTLV-1) is governed by actions on cellular regulatory signals, including modulation of specific cellular gene expression via activation of signaling pathways, acceleration of cell cycle progression via stimulation of cyclin-dependent kinase activity leading to retinoblastoma protein $(\mathrm{pRb})$ hyperphosphorylation and perturbation of survival signals. These actions control early steps in T cell transformation and development of Adult T cell leukemia (ATL), an aggressive malignancy of HTLV-1 infected T lymphocytes. Post-translational modifications of Tax by phosphorylation, ubiquitination, sumoylation and acetylation have been implicated in Tax-mediated activation of the NF-kB pathway, a key function associated with Tax transforming potential.
\end{abstract}

Results: In this study, we demonstrate that acetylation at lysine $\mathrm{K}_{346}$ in the carboxy-terminal domain of Tax is modulated in the Tax nuclear bodies by the acetyltransferase p300 and the deacetylases HDAC5/7 and controls phosphorylation of the tumor suppressor pRb by Tax-cyclin D3-CDK4-p21 CIP complexes. This property correlates with the inability of the acetylation deficient $\mathrm{K}_{346} \mathrm{R}$ mutant, but not the acetylation mimetic $\mathrm{K}_{346} \mathrm{Q}$ mutant, to promote anchorage-independent growth of Rat- 1 fibroblasts. By contrast, acetylation at lysine $\mathrm{K}_{346}$ had no effects on the ability of Tax carboxy-terminal PDZ-binding domain to interact with the tumor suppressor hDLG.

Conclusions: The identification of the acetyltransferase p300 and the deacetylase HDAC7 as enzymes modulating Tax acetylation points to new therapeutic targets for the treatment of HTLV-1 infected patients at risk of developing ATL.

Keywords: HTLV-1, Tax, Acetylation, CDK4, Transformation, Leukemia

\section{Background}

The oncogenic retrovirus human $\mathrm{T}$ cell leukemia virus type 1 (HTLV-1) causes both Adult $\mathrm{T}$ cell leukemia (ATL), a fatal malignancy that occurs in 2 to $4 \%$ of infected carriers after decades of asymptomatic infection, and a neurodegenerative disease called HTLV-1 associated myelopathy/tropical spastic paraparesis (HAM/TSP) [1-3]. Early steps in the transformation of $\mathrm{CD} 4^{+} \mathrm{T}$ lymphocytes by HTLV-1 have been associated with the oncogenic properties of its protein Tax.

\footnotetext{
*Correspondence: fbex@ulb.ac.be

'Institute for Microbiological Research J-M Wiame (IRMW), Laboratory of Microbiology, Université Libre de Bruxelles, 1, Avenue E. Gryson, Brussels, Belgium

Full list of author information is available at the end of the article
}

Four central activities have been linked to Tax transforming potential. First, Tax activates cellular signaling pathways, including the canonical [4-9] and non-canonical NF- $\kappa B$ [10-13], the SRF [14-16] and the AP1 $[17,18]$ pathways. This activity determines the expression of cellular genes involved in proliferation and differentiation of T lymphocytes. Second, Tax compromises genome stability by modulating the timing of replication origin activation and induction of reactive oxygen species (ROS) leading to generation of double strand breaks (DSB) $[19,20]$. In addition, Tax restricts appropriate response to DNA damages and suppresses apoptotic signals by inactivating the tumor suppressor p53 [21-25]. Third, Tax activates the pRb kinase activity

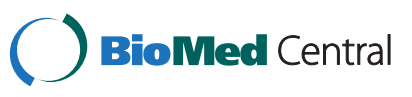


of CDK4/6-cyclin D3-p21 ${ }^{\mathrm{CIP}}$ complexes, resulting in pRb hyperphosphorylation and proteasomal degradation. This activity leads to the release of active E2F transcription factor and acceleration of cell cycle progression at the G1 to $S$ restriction point [26-30]. Fourth, Tax interacts with PDZ domain-containing proteins, including the tumor suppressors human homolog of Drosophila discs large protein (hDLG), Scribbe (hScrib) and MAGI-1, via its carboxy (C)-terminal PDZ binding motif (PBM) $E_{350} T_{E V} V_{353}$. These interactions result in perturbation of hDLG, hScrib and MAGI-1 functions in cell growth control [31-36]. The contribution of each of these oncogenic activities to Tax-mediated transforming phenotype and establishment of the leukemogenic process remains debatable. In addition, the observations that Tax expression is frequently turned off in leukemic $\mathrm{T}$ lymphocytes from ATL patients, and that the HTLV-1 bZIP factor (HBZ) promotes proliferation of ATL cells through its mRNA form, clouds the role of Tax in the maintenance of the transformed state [37].

Post-translational modifications of Tax, in the form of phosphorylation, poly-ubiquitination, and poly-sumoylation control both Tax intracellular localization as well as Tax-mediated activation of the NF-kB pathway [38-42]. This involves cooperation between phosphorylation dependent poly-ubiquitinated cytoplasmic forms of Tax and poly-sumoylated nuclear forms, resulting in the assembly of transcriptionally active Tax nuclear bodies (NBs) containing the RelA subunit of NF- $\mathrm{kB}$ and the transcriptional coactivator p300 [43]. The contribution of both ubiquitination and sumoylation in Tax-mediated activation of the NF- $\mathrm{kB}$ pathway has been recently challenged [44] and further discussed [45,46].

Our group has previously reported that the lysine residue at amino acid position 346 (previously designated K10) in the C-terminal domain of Tax is the target for acetylation by the acetyltransferase activity of p300. Acetylation of Tax favors transcription initiated at a chromatin-integrated, but not on a transiently transfected, NF- $\kappa B$ controlled promoter [47].

The acetylation targeted lysine $K_{346}$ is part of the 20 C-terminal amino acids of Tax, which have been directly implicated in Tax transforming activity. This region includes the PBM motif involved in Tax interaction with PDZ domain-containing proteins $[33,34]$ and a domain involved in genomic instability as evidenced by micronuclei formation $[48,49]$. In this work, we demonstrate that $K_{346}$ acetylation controls the ability of Tax to transform Rat-1 fibroblasts in the well-established model of colony formation in soft agar. Transformation of Rat- 1 fibroblasts by acetylated Tax correlates with stimulation of the kinase activity of CDK4-cyclin D3-p21 CIP complex, leading to $\mathrm{pRb}$ phosphorylation.

\section{Results}

Two acetylated forms of Tax are detected in various cell lines expressing Tax, including HTLV-1 infected T lymphocytes

Acetylation of a lysine residue modifies the isoelectric $\mathrm{pH}$ of proteins. Consequently, we used two-dimensional gel electrophoresis followed by Western Blotting (2DWestern) to identify the acetylated forms of Tax in lysates of 293T cells (Figure 1A and 1B) or T lymphocyte cell lines expressing Tax (Figure 1C). A monoclonal antibody (mAb) directed against Tax (anti-Tax) and a newly developed rabbit polyclonal antibody directed against the form of Tax acetylated at $K_{346}$ (anti-AcK ${ }_{346}$ Tax) were used to detect the various forms of Tax. Detection using the anti-Tax antibody revealed four species of molecular mass $40 \mathrm{kDa}$ in cells expressing wild type (WT) Tax (annotated 1, 2, 3 and 4). Among them, the two barely detected forms (2 and 4) were detected in WT Tax but not in $\mathrm{K}_{346} \mathrm{R}$ mutant expressing cells. When the same samples were analyzed by 2D-Western with the antiAcK $_{346}$ Tax antibody, two species of Tax were detected in WT Tax expressing cells, but no form of Tax was detected in cells expressing mutant $K_{346} R$. The alignment with an internal isoelectric point marker (not included in the area of gels presented in Figure 1A) indicated that the two acetylated species detected by the anti-AcK ${ }_{346}$ Tax antibody in WT Tax expressing cells comigrated with species 2 and 4 detected by the antiTax antibody.

To further characterize the acetylated forms of Tax, WT Tax was coexpressed with either the acetyltransferase p300 or the class IIa deacetylase HDAC7 and analyzed by 2D-Western (Figure 1B). Coexpression of p300 with WT Tax markedly increased the intensity of forms 2 and 4, whereas coexpression of HDAC7 resulted in the disappearance of these two acetylated forms. Coexpression of HDAC5, another class IIa deacetylase also led to reduced acetylation of Tax, contrary to coexpression of the class IIb deacetylase HDAC6 (data not shown). Furthermore, treatment of Tax expressing 293T cells with the deacetylase inhibitor Trichostatin A (TSA) resulted in a two fold increase of Tax acetylation (Additional file 1).

It is worthwhile noting that the two more acidic species of Tax detected by 2D-Western using the antiTax antibody (species 3 and 4) are phosphorylated, as indicated by metabolic labeling with ${ }^{32} \mathrm{P}$ orthophosphate (Additional file 2). Thus, separation of the modified forms of Tax by 2D-Western revealed four different $40 \mathrm{kDa}$ species including a non-modified form (NM, form 1), an acetylated form (Ac, form 2), a phosphorylated form ( $\mathrm{P}$, form 3 ) and an acetylated and phos phorylated form (Ac/P, form 4), with estimated percentages of NM 46\%, Ac 3\%, P 50\% and Ac/P $1 \%$ (Additional file 2). 


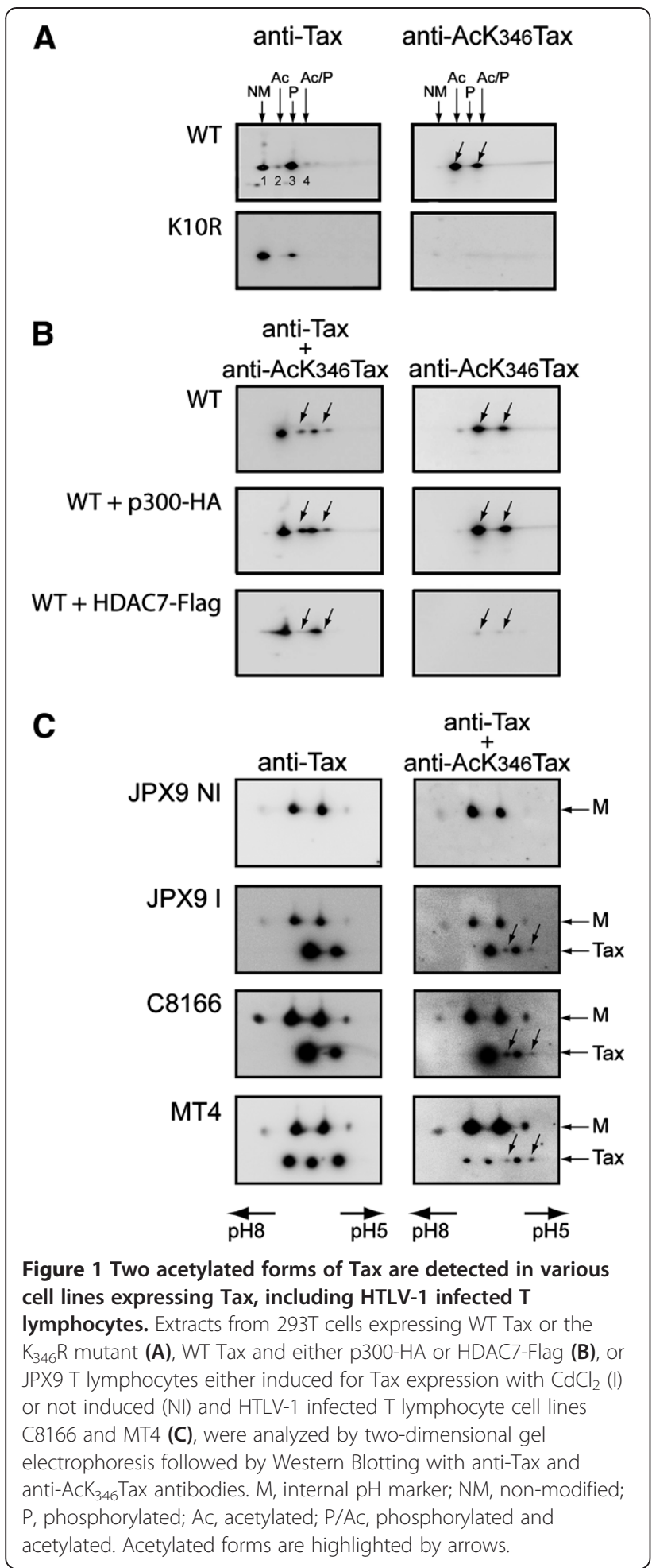

We next wanted to determine whether the two acetylated forms of Tax were also present in T lymphocyte cell lines expressing Tax. JPX-9 cells, that express Tax after induction with $\mathrm{CdCl}_{2}$, or HTLV-1 infected T lymphocyte cell lines, C8166 and MT4 were analyzed by 2D-Western
(Figure 1C). Each of these cell lines contained the Ac and Ac/P forms of Tax, in addition to the NM and P forms. The MT4 cell lines also expressed additional forms that did not comigrate with the NM, Ac, P and Ac/P forms identified above, possibly due to the presence in this cell line of multiple proviruses that express variant Tax proteins.

\section{Acetylation of Tax is modulated by $\mathrm{p} 300$ and HDAC7 in the Tax nuclear bodies}

Our previous studies indicated that both WT Tax and the acetylation deficient $\mathrm{K}_{346} \mathrm{R}$ mutant had similar intracellular distribution and colocalized with the acetyltransferase p300 in Tax NBs. In addition, cellular fractionation indicated that the acetylated form of Tax was predominantly localized in the nucleus, suggesting that the acetylated form of Tax could be present in the Tax NBs [47]. To directly test this possibility, HeLa cells expressing WT Tax or the $\mathrm{K}_{346} \mathrm{R}$ mutant were analyzed by immunofluorescence staining and confocal microscopy with the anti-AcK ${ }_{346} \mathrm{Tax}$ antibody (Figure 2A). Since overexpression of p300 increased the amount of the acetylated forms of Tax, whereas overexpression of HDAC7 resulted in the disappearance of these forms (see above), we included cells that coexpressed WT Tax or the $\mathrm{K}_{346} \mathrm{R}$ mutant with either p300-HA (Figure 2B) or HDAC7-Flag (Figure 2C). The intensity profiles of the immunofluorescence staining along lines drawn across the nuclei are shown.

Endogenous p300 had a speckled distribution in the nucleoplasm of cells in the absence of Tax expression. Expression of Tax confirmed the formation of Tax NBs containing endogenous p300 in WT Tax and mutant $\mathrm{K}_{346} \mathrm{R}$ expressing cells $[47,50]$. Interestingly, anti- $\mathrm{AcK}_{346} \mathrm{Tax}$ antibody detected the acetylated form of Tax in the Tax NBs formed by WT Tax, whereas no staining was observed in the Tax NBs assembled by mutant $\mathrm{K}_{346} \mathrm{R}$ (Figure 2A). Cytoplasmic Tax molecules that accumulated at the boundary of the nuclear envelope were detected only by anti-Tax and not by anti-AcK ${ }_{346}$ Tax antibody in both wild type and mutant $\mathrm{K}_{346} \mathrm{R}$ expressing cells.

Overexpressed p300-HA concentrated in the Tax NBs and markedly increased the intensity of the anti- $\mathrm{AcK}_{346} \mathrm{Tax}$ fluorescence staining in the Tax NBs formed by WT Tax as shown by the intensity profiles in Figure 2A (WT) and Figure 2B (WT + p300-HA). Staining intensity was at background level in mutant $\mathrm{K}_{346} \mathrm{R}$ expressing cells. Overexpressed HDAC7-Flag (or HDAC5-Flag, data not shown) had a rather diffuse distribution in the nucleoplasm in cells that did not express Tax and concentrated in the Tax-NBs formed by WT and mutant $\mathrm{K}_{346} \mathrm{R}$ Tax (Figure 2C). Concentration of HDAC7-Flag in the Tax NBs resulted in a marked reduction of the anti-AcK ${ }_{346}$ Tax fluorescence staining in the Tax NBs. The same results were obtained when HDAC5-Flag was expressed 


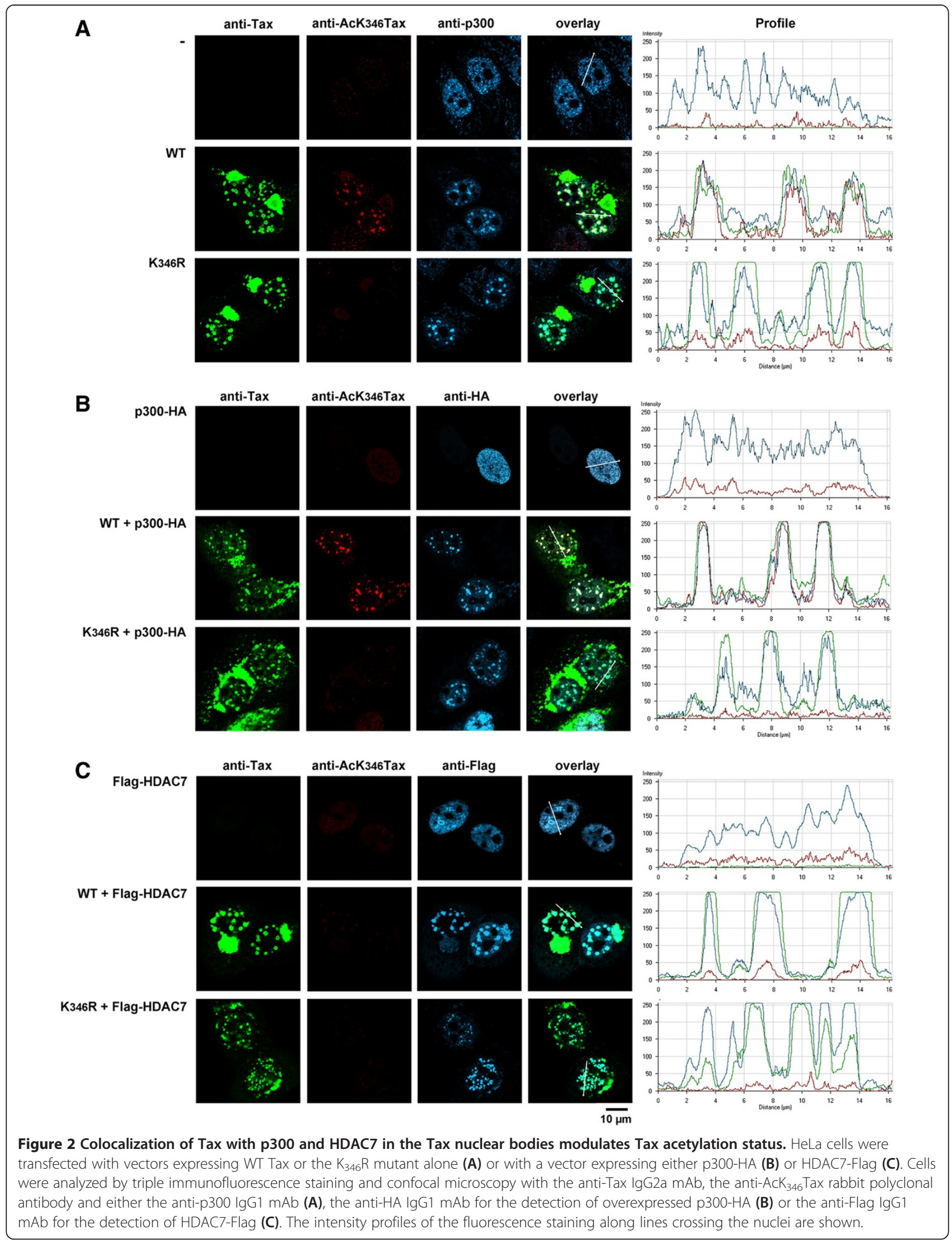


instead of HDAC7-Flag, whereas expression of the cytoplasmic deacetylase HDAC6 did not colocalize with Tax in the Tax NBs and had no effect on the level of acetylated Tax detected in Tax NBs (data not shown). These results demonstrated that the acetylated forms of Tax were present in the Tax NB. They also supported the idea that the acetylation status of Tax was modulated by p300 and HDAC7/5 in the Tax NBs. Furthermore, WT Tax and the acetylation deficient mutant $\mathrm{K}_{346} \mathrm{R}$ were similarly distributed in cytoplasmic hot spots and in nuclear bodies and overexpression of p300 or HDAC7, which have opposite effects on Tax acetylation status (see Figure 1), did not affect Tax intracellular localization. From these observations, we concluded that Tax acetylation status does not control Tax intracellular localization.

\section{Acetylation controls Tax-mediated transformation of Rat-1 cells}

Lysine $\mathrm{K}_{346}$ is part of the C-terminal domain of Tax involved in Tax transforming activity. We consequently tested whether acetylation controlled Tax ability to induce anchorage-independent growth of Rat-1 fibroblasts, a well-established method to determine Tax transforming potential. First, based on the previous observation that a glutamine residue mimics acetylated lysines [51], we constructed a Tax mutant in which lysine $K_{346}$ was
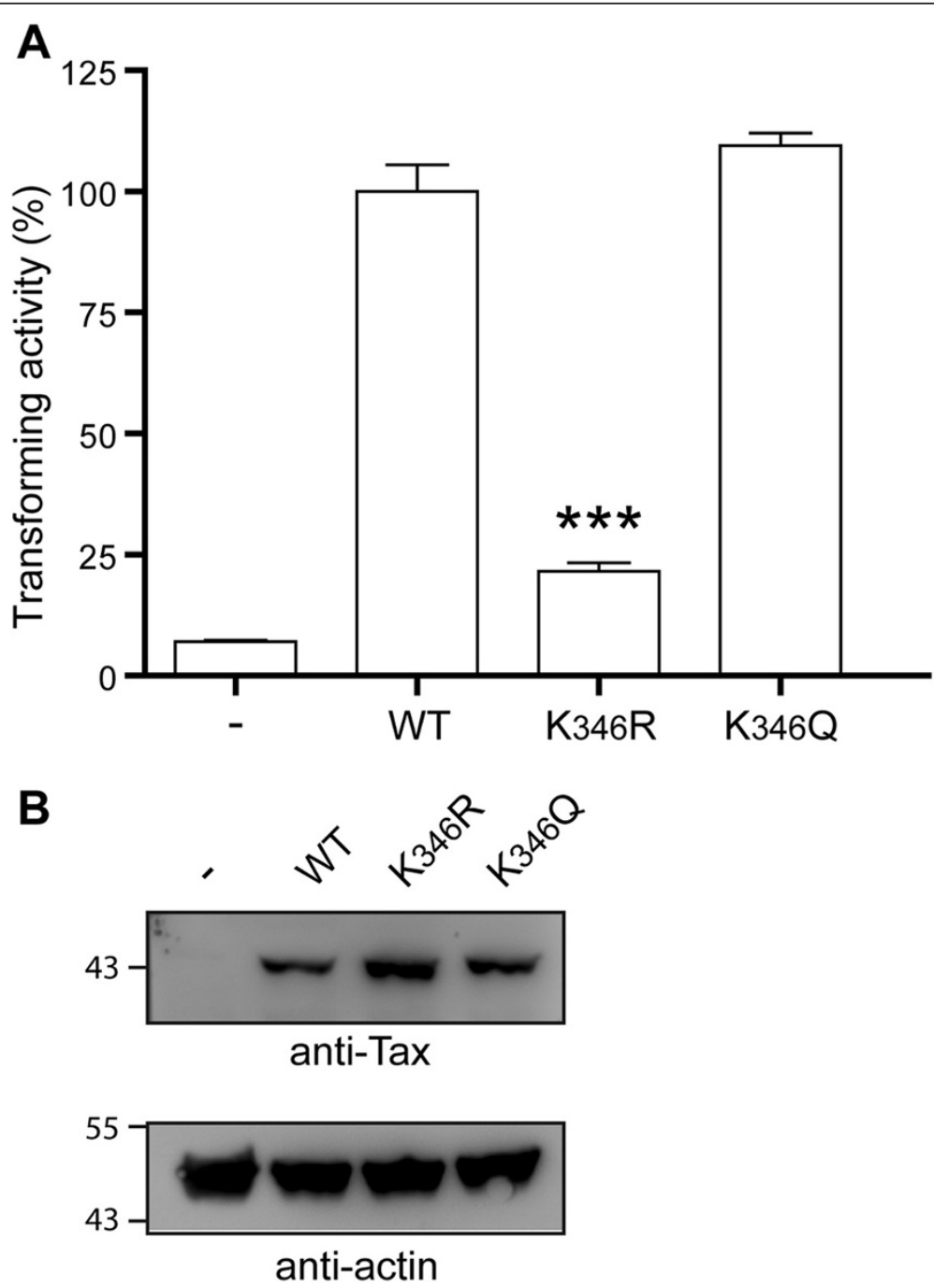

Figure 3 Acetylation controls Tax-mediated transformation of Rat-1 cells. (A) Rat-1 cells were stably transduced with lentiviral vectors expressing WT Tax or the $\mathrm{K}_{346} \mathrm{R}$ or $\mathrm{K}_{346} \mathrm{Q}$ mutants. Cells were plated in soft agar and colonies were counted 6 weeks later. The transforming activity expressed as the percentages of colonies formed relatively to WT Tax are the average of 3 independent experiments. ${ }^{* * *}: p<0.05$.

(B) Before plating, aliquots of the Rat-1 cells transduced with the lentiviral vectors were lysed and tested for expression of Tax by Western Blot with anti-Tax and anti-actin antibodies. 
replaced by a glutamine residue (mutant $\mathrm{K}_{346} \mathrm{Q}$ ). Mutant $\mathrm{K}_{346} \mathrm{Q}$ had a distribution very similar to WT Tax or mutant $\mathrm{K}_{346} \mathrm{R}$, with concentration in cytoplasmic structures associated with the Golgi and colocalization with p300 in nuclear bodies. As expected, this mutant was not detected by the anti-AcK ${ }_{346}$ Tax antibody (data not shown). Then, Rat-1 cells were stably transduced with either lentiviral control vector (Rat/LV) or lentiviral vectors expressing WT Tax (Rat/LV-WT), mutant $\mathrm{K}_{346} \mathrm{R}$ (Rat/LV- $\mathrm{K}_{346} \mathrm{R}$ ) or mutant $\mathrm{K}_{346} \mathrm{Q}$ (Rat/LV-K $\left.{ }_{346} \mathrm{Q}\right)$.

FACS analysis was used to determine that about $75 \%$ of the transduced Rat-1 cells expressed WT Tax or $\mathrm{K}_{346} \mathrm{R}$ or $\mathrm{K}_{346} \mathrm{Q}$ after 7 days of culture in the presence of $10 \mu \mathrm{g} / \mathrm{ml}$ of blasticidin (data not shown). The cells were plated in soft agar and the number of colonies formed after 6 weeks was estimated (Figure 3A). Aliquots of the transduced Rat-1 cells were also tested for expression of WT or mutant Tax (Figure 3B). The percentage of anchorage-independent colonies formed by Rat/LV-K ${ }_{346} \mathrm{R}$ was only $20 \%$ as compared to Rat/LV-WT, whereas Rat/LV-K ${ }_{346} \mathrm{Q}$ formed anchorage-independent colonies at the same rate as Rat/LV-WT Tax. Quantitation of WT or mutant Tax expressed in the transduced Rat-1 cells indicated that the reduced transformation rate of Rat/ $\mathrm{LV}-\mathrm{K}_{346} \mathrm{R}$ did not result from reduced expression of this mutant. In addition, the Tax nucleotide sequence of three transformed Rat/LV-WT, Rat/LV-K ${ }_{346} \mathrm{R}$ and Rat/LV-K $\mathrm{K}_{346} \mathrm{Q}$ clones was determined to assure the correct WT or mutated sequence at residue 346. We concluded that acetylation controls Tax transforming activity in Rat-1 fibroblasts.

\section{Transformation of Rat-1 cells does not depend on} Tax-mediated activation of the NF-кB pathway

Activation of the NF- $\kappa B$ pathway is one of the Tax functions critical for cellular transformation [52,53]. Therefore, we tested the ability of Tax to activate the NF- $\kappa B$ pathway in the Rat/LV-WT cells by transfection of a $\kappa B$-luc reporter construct. Tax-mediated activation of the HTLV-1 promoter via the ATF/CREB pathway was also tested as a control for Tax transcriptional activity by transfection of the HTLV-1

\section{A}

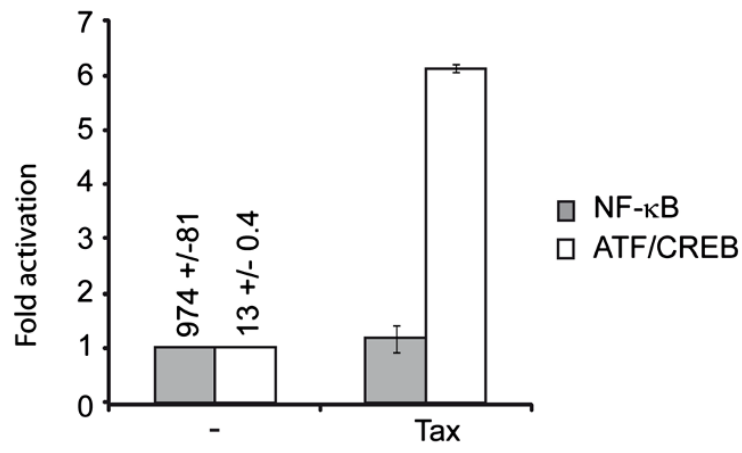

B
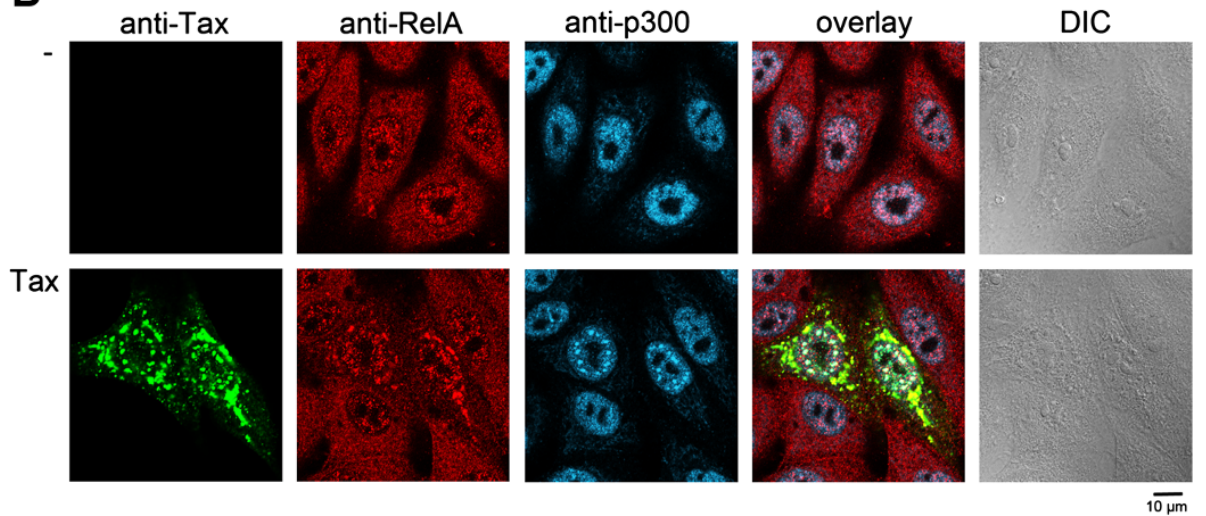

Figure 4 Activation of the NF-KB and ATF/CREB pathways in Rat-1 cells expressing wild type Tax. (A) Rat-1 cells transducted with either the control lentiviral vector (-) or with the lentiviral vector expressing wild type Tax (Tax) were transfected with $0.5 \mu \mathrm{g}$ of kB-luc (grey bars) or $0.5 \mu \mathrm{g} \mathrm{HTLV}-1$ LTR-luc (white bars) reporter constructs and $0.5 \mu \mathrm{g}$ of pRL-TK-luc. The results are presented as fold increase of luciferase activities in Rat-1 cells expressing Tax relatively to control Rat-1 cells. The values are averages of three independent experiments, with standard deviations. The numbers above the bars represent basal luciferase activities in control Rat-1 cells. (B) Control Rat-1 cells (-) or Rat-1 cells expressing Tax (Tax) were analyzed by triple immunofluorescence staining with anti-Tax IgG2a mAb, anti-RelA rabbit polyclonal antibody and anti-p300 IgG1 mAb followed by confocal microscopy. 
LTR-luc reporter construct (Figure 4A). WT Tax expressed in the Rat-1 transduced cells was unable to increase basal NF- $\mathrm{KB}$ activity although it increased activation of transcription initiated at the HTLV-1 LTR by a factor of 6 . Interestingly, comparison of the luciferase activities resulting from activation of the NF- $\mathrm{kB}$ and ATF/CREB pathways in control Rat-1 cells (974 versus 13 light units) strongly suggested that the NF- $\mathrm{kB}$ pathway was constitutively activated in Rat-1 cells, independently of Tax expression. To test this possibility, we checked whether the RelA subunit of NF- $\mathrm{kB}$ was present in the nuclei of Rat-1 cells that did not express Tax, by using immunofluorescence staining and confocal microscopy. The images presented in Figure 4B clearly indicated the RelA was present in the nuclei of Rat-1 cells. Expression of Tax in these cells resulted in the colocalization of RelA and p300 in the Tax NBs, like previously observed [47], but did not alter the level of RelA already present in the nuclei. Thus, transformation of Rat-1 cells appears to be independent of Tax-mediated NF- $\mathrm{kB}$ activation, but might depend on constitutive activation of the NF- $\mathrm{KB}$ pathway in these cells. This observation strongly suggests that the previously described $50 \%$ reduction in activation of a NF- $\mathrm{kB}-$ controlled promoter integrated in the chromatin by mutant $K_{346} \mathrm{R}$ [47] cannot justify the loss of transforming activity of this mutant.

\section{Acetylation does not control the interaction of Tax with the PDZ domain-containing proteins, hDLG}

Since the acetylation targeted lysine $\mathrm{K}_{346}$ lies close to the PBM $\left(E_{350} \mathrm{TEV}_{353}\right)$, which controls Tax interaction with hDLG and contributes to Tax transforming activity $[33,34]$, we asked whether Tax acetylation had consequences on the interaction of Tax with hDLG. 293T cells were cotransfected with vectors for expression of either WT Tax or the $\mathrm{K}_{346} \mathrm{R}$ mutant and a vector expressing HA-hDLG. Western Blot analysis of cells lysates immunoprecipitated with anti-Tax revealed that both mutant $\mathrm{K}_{346} \mathrm{R}$ and WT Tax associated with hDLG (Figure 5A). We also tested the intracellular localization of WT Tax or the $K_{346} \mathrm{R}$ mutant in 293T cells overexpressing HA-hDLG by immunofluorescence staining and confocal microscopy (Figure 5B). Overexpressed HA-hDLG had a rather diffuse distribution in the cytoplasm and coexpression of WT Tax or the $K_{346} \mathrm{R}$ mutant with HA-hDLG led to the redistribution of both WT or mutant Tax and HA-hDLG to cytoplasmic speckled structures, in which they colocalized. These results support the conclusion that the interaction of the Tax PBM motif with hDLG is not regulated by the acetylation status of Tax.

\section{Acetylation controls the ability of Tax to stimulate phosphorylation of pRb by CDK4-cyclin D3-p21 complexes}

Tax-mediated activation of the $\mathrm{pRb}$ kinase activity of CDK4/6-cyclin D3-p21 ${ }^{\text {CIP }}$ complexes contributes to cell transformation by accelerating cell cycle progression at the G1 to $S$ restriction point [26-30]. We thus asked whether Tax acetylation was involved in activation of the pRb kinase activity of these complexes. First, we tested the experimental conditions that led to increased $\mathrm{pRb}$ kinase activity of CDK4-cyclin D3 complexes in the presence of Tax (Figure 6A). Intracellular CDK4-D-type cyclin complexes are predominantly associated with CDK inhibitors (CKI) p21 or p27. At low stoichiometric binding ratio, p21 favors formation of active CDK4cyclin D3 complexes, but higher stoichiometric ratios of p21 binding inhibit CDK4 activity [54-57].

The formation and the kinase activity of the CDK4cyclin D3-p21 complexes were tested in $\mathrm{CHO}$ cells cotransfected with vectors expressing WT Tax-HA, CDK4, cyclin D3 and either low dose $(0.2 \mu \mathrm{g})$ or high dose $(2 \mu \mathrm{g})$ of vector expressing p21. The cell extracts were immunoprecipitated with an anti-cyclin D3 mAb and subsequently analyzed by Western Blotting using anti-cyclin D3, anti-CDK4, anti-p21 and anti-HA antibodies to determine the composition of the immunoprecipitated complexes. These complexes were then assayed in vitro for phosphorylation of a pRb fragment containing threonine 826, a known target of CDK4. The diagram of Figure $6 \mathrm{~A}$ represents the relative CDK4 specific kinase activity calculated by estimating the quantity of phosphorylated $\mathrm{pRb}$ fragment on the Western Blot reported to equal amount of CDK4 in the complexes.

Expression of p21 in the absence of Tax resulted in stabilization of CDK4-cyclin D3 complexes, in a p21 dosedependent manner. The specific CDK4 kinase activity of these complexes (grey bars) was reduced by factors 2 and 25 when the complexes were formed in the presence of low or high dose of $\mathrm{p} 21$, respectively. These results are in accordance with the reported consequences of p21 dosage on stabilization and inhibition of CDK4-cyclin D3 complexes [56-58]. Stabilization of the CDK4-cyclin D3 complexes in a p21 dose-dependent manner was also observed in the presence of Tax and these complexes included Tax. However, these complexes had a kinase activity (white bars) that was markedly higher than that of the complexes assembled in the absence of Tax, when high dose of p21 was expressed (8.6 fold increase). Expression of Tax in the absence or with a low dose of p21 gave kinase activities similar to that in the absence of Tax. These results indicate that inclusion of Tax in the CDK4-cyclin D3-p21 complexes partly relieves the inhibitory action of $\mathrm{p} 21$ on the $\mathrm{pRb}$ kinase activity of the complexes. These results are in accordance with previous observations $[27,28]$. 
A

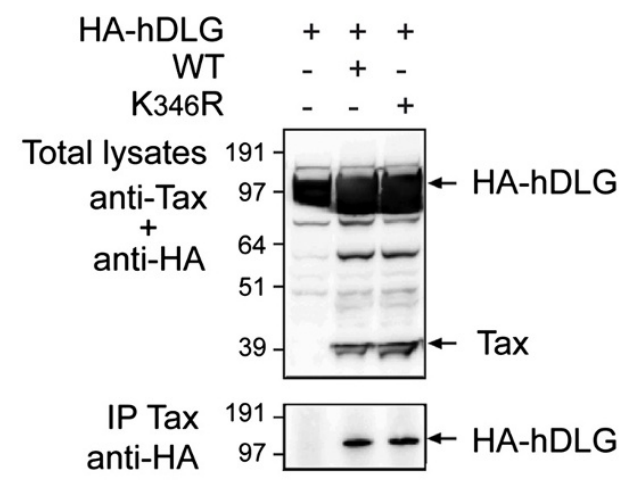

B
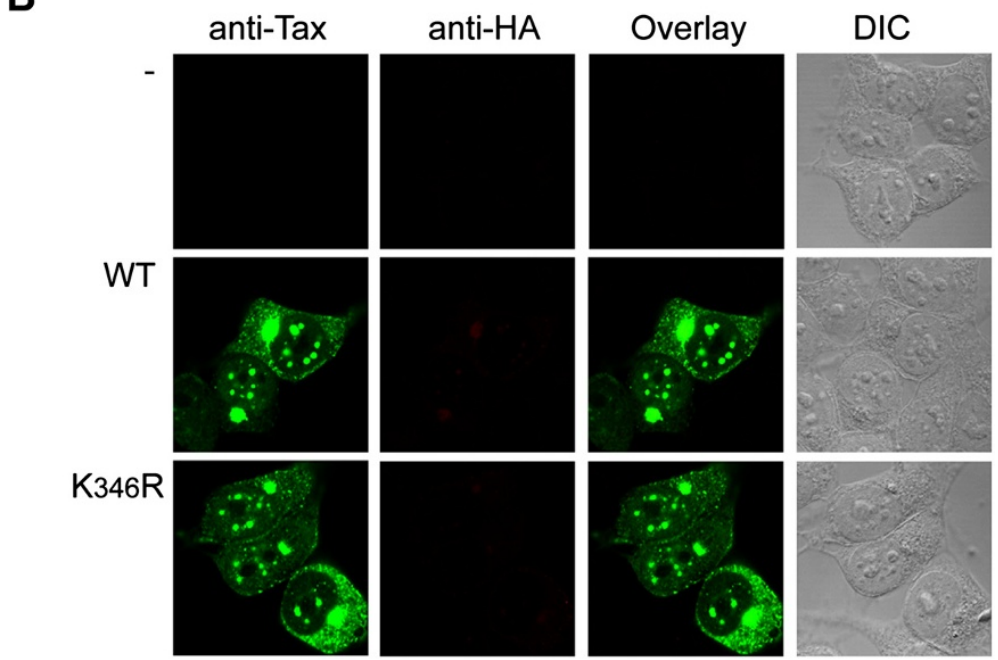

HA-hDLG
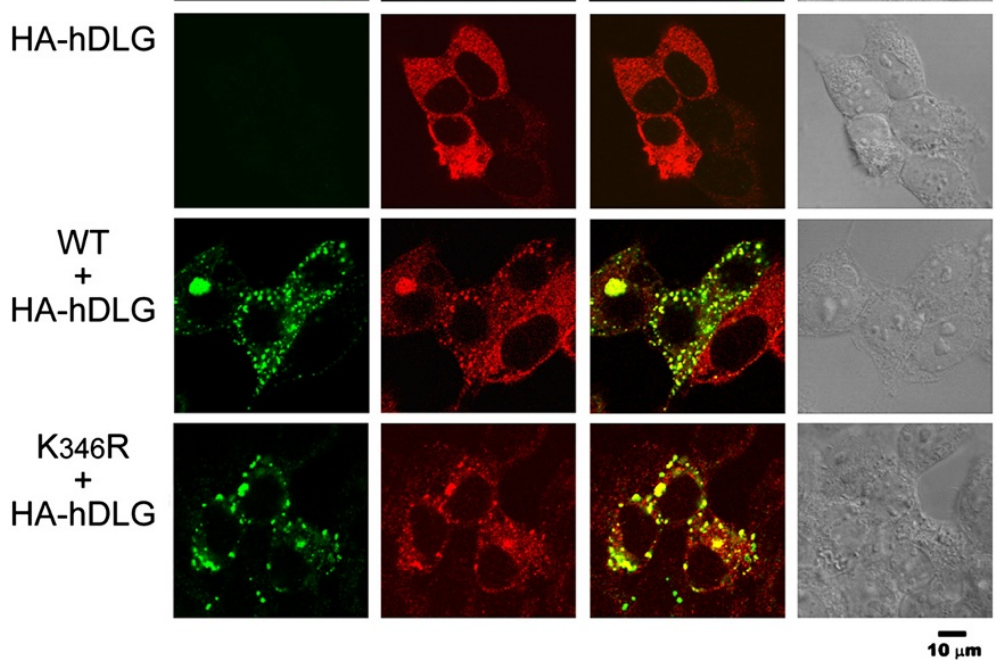

Figure 5 Acetylation does not prevent interaction of the Tax with PDZ-binding protein hDLG. (A) 293T cells transfected with vectors expressing HA-hDLG and WT Tax or mutant $\mathrm{K}_{346} \mathrm{R}$ were subjected to anti-Tax immunoprecipitation (IP Tax) and analyzed by Western Blotting with anti-HA antibody. Total lysates were analyzed by Western Blotting with anti-Tax and anti-HA antibodies. (B) 293T cells expressing WT Tax or the $\mathrm{K}_{346} \mathrm{R}$ mutant alone or with HA-hDLG were analyzed by immunofluorescence staining and confocal microscopy with anti-Tax IgG2a mAb and anti-HA rabbit polyclonal antibody for the detection of HA-DLG. 


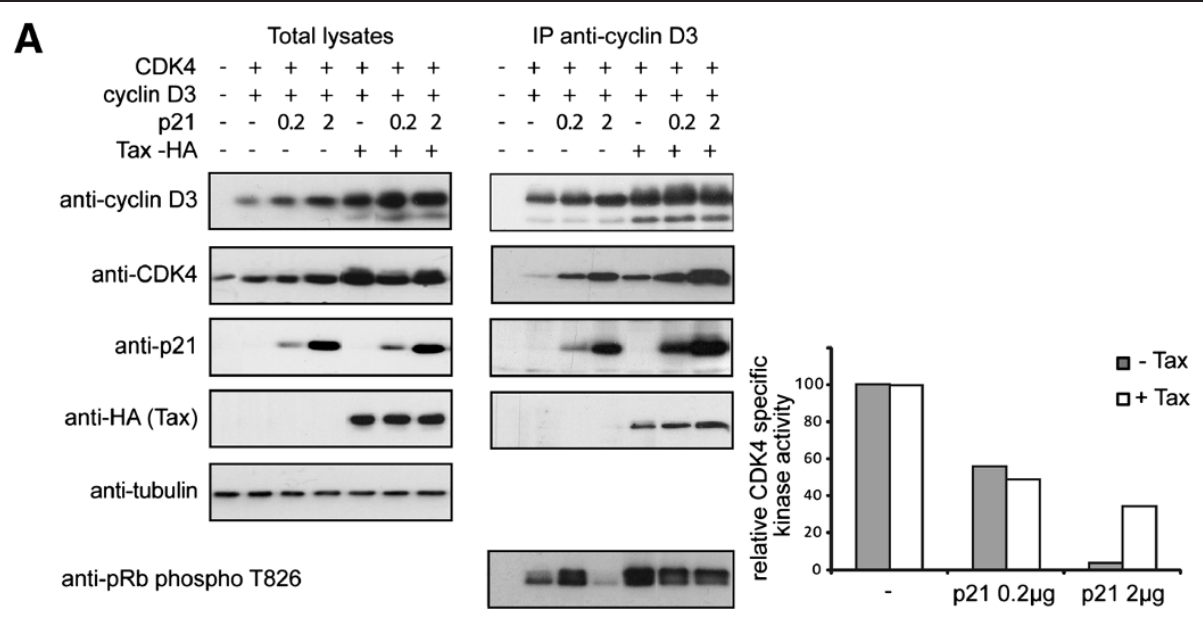

B
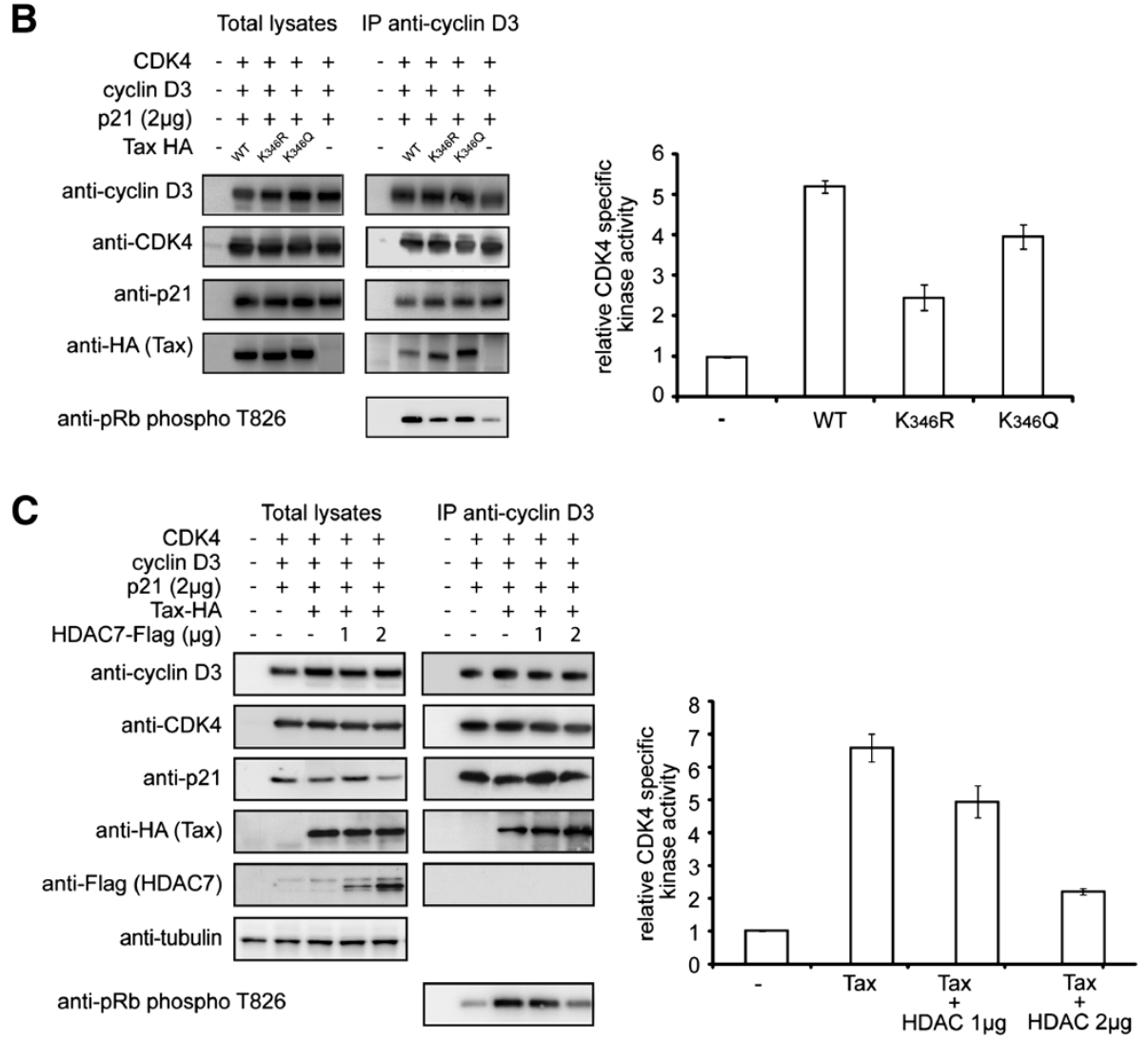

Figure 6 Acetylation controls the ability of Tax to stimulate phosphorylation of pRb by CDK4-cyclin D3-p21 ${ }^{\mathrm{CIP}}$ complexes. CHO cells were transfected with vectors expressing CDK4, cyclin D3 and either 0.2 or $2 \mu \mathrm{g}$ of vector expressing p21 with or without a vector expressing Tax-HA (A), or $2 \mu \mathrm{g}$ of vector expressing p21 with vectors expressing WT or mutant $\mathrm{K}_{346} \mathrm{R}$ or $\mathrm{K}_{346} \mathrm{Q}$ Tax-HA (B), or $2 \mu \mathrm{g}$ of vector expressing p21 and WT Tax-HA and 1 or $2 \mu \mathrm{g}$ of vector expressing HDAC7-Flag (C). Total lysates were immunoprecipitated with the anti-cyclin D3 mAb and both the total lysates and the immunoprecipitated complexes (IP anti-cyclin D3) were analyzed by Western Blotting using antibodies shown on the left side of the lanes. The immunoprecipitated complexes were also analyzed using an in vitro pRb phosphorylation assay. The diagrams represent the relative CDK4 specific activity obtained by quantitation of the intensity of the pRb phosphorylated species on the blots reported to equal amount of CDK4 in the complexes. One representative experiment is presented in panel A. Error bars were calculated for two independent experiments in panels $\mathbf{B}$ and $\mathbf{C}$. 
We then tested whether acetylation of Tax had consequences on the formation and kinase activity of the complexes. $\mathrm{CHO}$ cells were cotransfected with vectors expressing CDK4, cyclin D3, the high dose $(2 \mu \mathrm{g})$ of vector expressing p21 and vectors expressing either WT Tax, the non-acetylated $\mathrm{K}_{346} \mathrm{R}$ mutant or the acetylation mimetic $\mathrm{K}_{346} \mathrm{Q}$ mutant (Figure $6 \mathrm{~B}$ ). Both mutants $\mathrm{K}_{346} \mathrm{R}$ and $\mathrm{K}_{346} \mathrm{Q}$ associated with the complexes, but the specific kinase activity of the complexes containing mutant $\mathrm{K}_{346} \mathrm{R}$ was decreased by a factor 2 as compared to complexes containing WT Tax or the acetylation mimetic $\mathrm{K}_{346} \mathrm{Q}$ mutant.

To further analyze the role of Tax acetylation in stimulation of CDK4 kinase activity, we tested whether overexpression of HDAC7, which strongly deacetylates Tax, had consequences on the ability of the CDK4-cyclin D3-p21-Tax complexes to phosphorylate pRb (Figure 6C). Expression of HDAC7 had no consequences on the formation of the CDK4-cyclin D3-p21-Tax complexes, but reduced the ability of these complexes to phosphorylate $\mathrm{pRb}$ in a dose-dependent manner. These results indicated that acetylation deficiency did not prevent the association of Tax with CDK4-cyclin D3-p21 complexes, but resulted in a reduced capacity of these complexes to bypass p21 inhibition.

Phosphorylation of $\mathrm{pRb}$ results in the release of transcriptionally active free E2F. To further examine the mechanism involved in Tax acetylation-dependent transforming activity, we analyzed the luciferase activity of the E2F controlled p3xE2F-luc reporter construct in $\mathrm{CHO}$ cells transfected with the plasmids expressing CDK4, cyclin D3 and p21 and either WT Tax or the

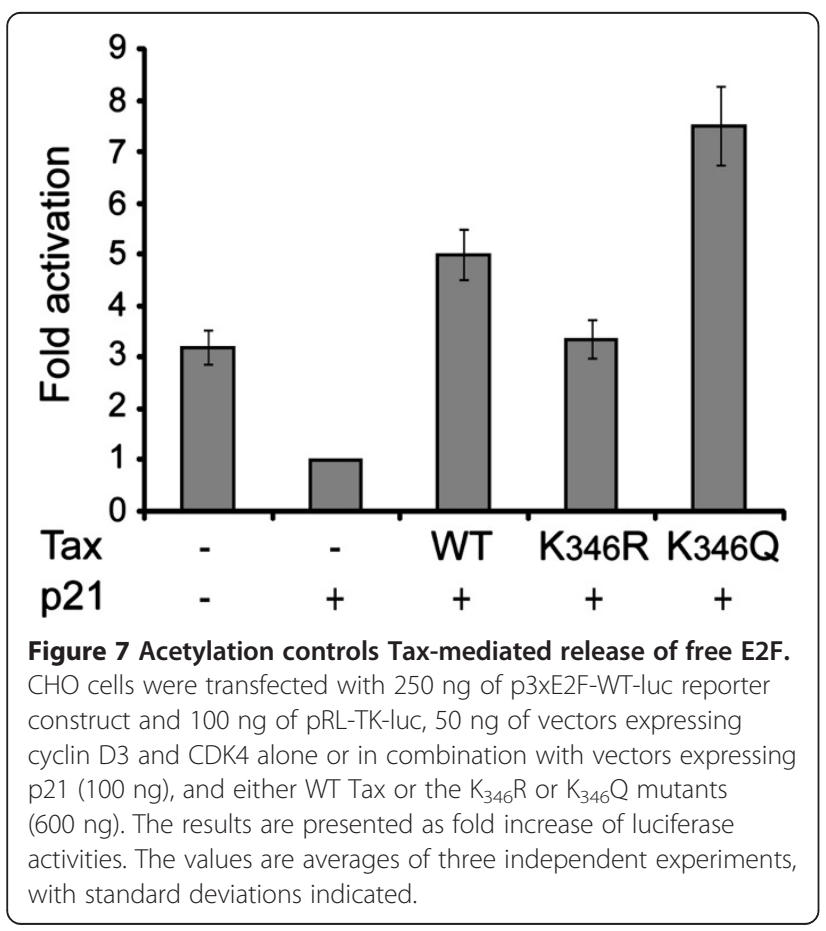

$K_{346} R$ or $K_{346} Q$ mutants like reported in Figure $6 B$. Figure 7 indicates that activation of the E2F controlled promoter was reduced following expression of p21 and that WT Tax expression resulted in the bypass of p21 repression in an acetylation-dependent manner, thus mimicking the effects observed on $\mathrm{pRb}$ phosphorylation.

\section{Discussion}

In this work, we have demonstrated that acetylation at lysine $\mathrm{K}_{346}$ in the $\mathrm{C}$-terminal domain of Tax plays a critical role in Tax capacity to transform Rat-1 fibroblasts and in rendering the pRb kinase activity of CDK4-cyclin D3-p21Tax complexes resistant to p21 inhibition. These conclusions are based on the observations that the acetylation deficient $\mathrm{K}_{346} \mathrm{R}$ mutant, but not the acetylation-mimetic $\mathrm{K}_{346} \mathrm{Q}$ mutant, is deficient for both transformation of Rat-1 fibroblasts and activation of the CDK4 complexes stabilized by $\mathrm{p} 21$.

Here, we identify two acetylated forms of Tax, including an acetylated and phosphorylated form, that are both present in fibroblasts overexpressing Tax and in HTLV-1 infected $\mathrm{T}$ lymphocytes. The fraction of acetylated forms was estimated at about 4 percent of all four $40 \mathrm{kDa}$ Tax species. This low percentage clearly has physiological significance since we demonstrate that loss of Tax acetylation results in markedly reduced transforming activity. It is now well recognized that the biological consequences of modified forms are not proportional to the small fraction of substrate that is modified [59]. It is also worth noting that the acetylated Tax forms are concentrated in the Tax NBs, along with a variety of effectors including the acetyltransferase p300 and the deacetylase HDAC7, which might compete to regulate Tax acetylation status in a dynamic process. Finally, the presence of acetylated Tax in the Tax NBs supports our previous observation using cell fractionation experiments indicating that acetylated Tax is essentially distributed in the nucleus [47]. The contributions of each acetylated form to the transformation phenotype and determination of the phosphorylated residue need further investigations.

In addition to consequences on $\mathrm{pRb}$ phosphorylation, our previous studies indicated that acetylated Tax favored activation of a NF- $\mathrm{kB}$ controlled promoter, when the reporter construct was integrated in the chromatin [47]. Our results suggest that the transformation phenotype observed in Rat- 1 cells does not depend on Tax ability to activate gene expression from a $\mathrm{kB}$-controlled promoter but might depend on constitutive NF-kB activation in Rat-1 cells.

\section{How does Tax acetylation alter the kinase activity of CDK4?}

Mechanistically, acetylation of Tax acts on stimulation of the pRb kinase activity of CDK4-cyclin D3-p21 complexes 
in $\mathrm{CHO}$ cells resulting in increased free E2F available for activation of an E2F-controlled promoter. However, acetylation was dispensable for the association of Tax with the CDK4-cyclin D3-p21 complexes. This concept is supported by the observations that WT Tax as well as mutants $K_{346} \mathrm{R}$ and $\mathrm{K}_{346} \mathrm{Q}$ were associated with the CDK4-cyclin D3-p21 complexes, and that WT Tax or the acetylation-mimetic $\mathrm{K}_{346} \mathrm{Q}$ mutant were more potent in preventing the inhibitory action of the CDK inhibitor p21 and in increasing transcription from the E2F-controlled promoter than the acetylation deficient $\mathrm{K}_{346} \mathrm{R}$ mutant. In addition, expression of the deacetylase HDAC7, which markedly reduced Tax acetylation, did not affect the association of Tax with the complexes, but prevented stimulation of the pRb kinase activity of the complexes by WT Tax, in a dose-dependent manner.

It will be important to determine how acetylation of Tax acts to prevent the inhibitory action of p21. Binding of p21 through both its cyclin-binding motif (Cy1) and its CDK-binding motif $(\mathrm{K})$ is required for inhibition of the kinase activity of the CDK4-cyclin D complex [60]. Previous studies indicated that the N-terminal 40 amino acids of Tax directly interact with the PSTAIRE Nterminal domain of CDK4 and that Tax also interacts with cyclin D3. Most likely, one of these interactions might affect the binding of p21 through one of its cyclin/CDK interaction motifs. Tax interaction would thus allow the stabilization by p21 of abundant CDK4-cyclin D3 complexes that remain partially active despite high p21 expression levels, leading to enhancement of both phosphorylation of $\mathrm{pRb}$ and steady state level of free E2F, with subsequent acceleration of progression from the G1 to the S phase of the cell cycle $[27,28]$. In addition, Tax stimulates expression of p21 at the transcriptional level in fibroblasts overexpressing Tax and in HTLV-1 infected T lymphocytes $[61,62]$, and induces phosphorylation of cyclin D3 [26]. Importantly, our results indicate that lack of acetylation does not affect the ability of Tax $\mathrm{K}_{346} \mathrm{R}$ to associate with CDK4-cyclin D3-p21 complexes. The $\mathrm{K}_{346}$ acetylated $\mathrm{C}$-terminal domain of Tax might recruit a kinase involved in phosphorylation of critical residues of the CDK4-cyclin D3-p21 complex such as threonine 172 in the CDK4 activation loop [58]. Alternatively, since an extensive number of kinases regulate CKIs to control their function, localization and stability [63], one could speculate that Tax recruits a kinase involved in the control of p21 inhibitory function.

Previous studies indicated that, in $\mathrm{T}$ lymphocytes cell lines and HTLV-1 infected lymphocytes, but not in fibroblasts, Tax activates cyclin D2 and CDK6 promoters via activation of the NF- $\mathrm{kB}$ pathway resulting in cell cycle progression [64]. In addition, stable p21-cyclin D2-CDK4 complexes active in phosphorylation of $\mathrm{pRb}$ were detected in HTLV-1 infected T cells [65]. Further studies will be important to determine whether Tax acetylation also controls cell cycle progression in T-cells and whether the activity of different complexes such as p21-cyclin D2-CDK6 are modulated by Tax acetylation in T cells.

\section{How does Tax C-terminal region function in cellular transformation?}

The acetylation targeted lysine $K_{346}$ is part of the $C$ terminal domain of Tax that otherwise contains two critical functions participating in Tax transforming potential. These include the four C-terminal amino acids which form a PBM motif for interaction with the hDLG and hScrib and MAGI-1 tumor suppressors [11,31,33,34], and a region involved in micronuclei formation $[48,66]$. Here we show that the lack of acetylation of the $K_{346} \mathrm{R}$ mutant does not affect its ability to interact with hDLG or to be redistributed by hDLG into cytoplasmic speckles. We conclude that activation of the kinase activity of CDK4-cyclin D3-p21 complexes by acetylated Tax and interaction with hDLG are distinct functions that both participate in Tax transforming activity, in a necessary, but not sufficient manner.

Comparison of the transforming activities of the Tax proteins of HTLV-1 (Tax-1) and HTLV-2 (Tax-2), which markedly differ in pathogenicity, might reveal information about the role of the C-terminal domain in Tax-induced transformation. The weakly transforming Tax-2 protein shares a high degree of amino acid similarity with Tax-1, but the two proteins have divergent $\mathrm{C}$-terminal domains. In addition, Tax-2 does not include a functional PBM and does not induce micronuclei formation [67]. Furthermore, the chimera formed by fusion of the C-terminal domain of Tax-1 to the C-terminus of Tax-2 displays increased capacity to promote proliferation of human PBMCs as compared to Tax-2 $[34,68]$. Studies are underway to determine whether the acetylation status of Tax- 2 concurs with the absence of a PBM to determine its reduced transforming activity.

\section{How do Tax NBs function in cellular transformation?}

Tax NBs control two central functions in Tax transforming activity. These include activation of gene expression via the NF-kB pathway $[39,40]$, and sequestration of effectors involved in DNA repair [24,25]. Our finding showing that the acetylated forms of Tax and the enzymes that modulate Tax acetylation are concentrated in Tax NBs, incriminates these structures in both Tax acetylation and transforming activity. This conclusion is also supported by our previous observation that mutants deficient for sumoylation and subsequent assembly of the Tax NBs have a markedly reduced acetylation status [47]. These results support the idea that transformation by Tax is the consequence of a cascade linking Tax sumoylation- 
dependent acetylation and activation of cyclin-dependent kinase CDK4 for cell cycle progression.

\section{Conclusions}

\section{Is deacetylase therapy appropriate for ATL?}

Our work questions whether treatments of ATL patients with drug regimens that include inhibitors of deacetylases are appropriate since such treatments could theoretically increase Tax acetylation [69,70]. It will be important to determine if Tax acetylation promotes transformation of HTLV-1 infected T lymphocytes and if HDAC inhibitors stimulates Tax acetylation in T-cells. Determination of the actual enzymes that regulate Tax acetylation in HTLV-1 infected patient samples would provide new therapeutic targets for the treatment of HTLV-1 infected patients who present a risk of developing ATL.

\section{Methods}

\section{Cell culture and transfection}

293T, 293GP2, HeLa and Rat-1 cells were maintained in Dulbecco's modified Eagle's medium (DMEM), and CHO cells were maintained in F12 HAM medium, which were supplemented with $2 \mathrm{mM}$ L-Glutamine, $10 \%$ fetal calf serum (FCS), 1\% penicillin-streptomycin and $1 \mathrm{mM}$ sodium pyruvate (Life technologies, Paisley, UK). Cell lines were transfected using the Transit LT-1 reagent (Mirus Bio LLC, Madison, USA) according to the manufacturer's instructions. The HTLV-1 infected T lymphocyte cell lines C8166 and MT4 were maintained in RPMI medium with Glutamax-I (Life technologies, Paisley, UK) supplemented with 10\% FCS. Expression of Tax by JPX9, a derivative of Jurkat cells containing an inducible tax gene under the control of the metallothionein promoter, was induced by supplementing $30 \mu \mathrm{M} \mathrm{CdCl} 2$ to the RPMI medium for $16 \mathrm{~h}$ [71]. Trichostatin A (TSA) was purchased from Sigma-Aldrich (Belgium).

\section{Expression vectors}

The vectors for expression of WT or $\mathrm{K}_{346} \mathrm{R}$ Tax mutant and p300-HA were previously described [47], as well as vectors for expression of CDK4 and cyclin D3 [58]. Mutant $\mathrm{K}_{346} \mathrm{Q}$ was generated by PCR based site-directed mutagenesis. Vector for expression of HA-hDLG was provided by L. Banks [72], HDAC7-Flag was from F. Dequiedt [73], and $\mathrm{p} 21^{\mathrm{CIP}}$ (referred to as p21) was from L. Hengst (Innsbruck). The luciferase reporter constructs $k B$-luc (Promega), HTLV-1-LTR-luc [39], and p3xE2F-luc [74] were used in luciferase assays.

\section{Transformation of Rat-1 fibroblasts in soft agar}

For lentiviral vector construction, WT, $\mathrm{K}_{346} \mathrm{R}$ and $\mathrm{K}_{346} \mathrm{Q}$ Tax coding sequences were inserted into the pCSEF-IRESbsd lentiviral vector kindly provided by M. Fujii [11]. This generated the pCSEF-IRES-bsd control, pCSEF-Tax WT,
pCSEF-Tax $\mathrm{K}_{346} \mathrm{R}$ and pCSEF-Tax $\mathrm{K}_{346} \mathrm{Q}$ lentiviral vectors, which were transfected in $2 \times 10^{6} 293 \mathrm{GP} 2$ packaging cells together with pCAG-HIVgp and pCMV-VSV-G-RSV-Rev to produce viral particles. Production of lentiviral vectors expressing Tax, stable transduction of Rat- 1 cells and transformation assays have been described [20].

\section{Antibodies}

The antibody recognizing the $\mathrm{K}_{346}$ acetylated form of Tax was obtained by immunizing rabbits with a synthetic peptide $\left(\mathrm{H}_{2} \mathrm{~N}\right.$-CEPPSEK(Ac)HFRET-CONH $\left.{ }_{2}\right)$. Specific antibodies were enriched by selection against both the acetylated and the non-acetylated peptides (Eurogentec, Seraing, Belgium). The specificity of the purified antibody was tested by ELISA (Additional file 3). The mouse IgG2a antiTax-1 mAb from hybridoma 168-A51 was obtained from the AIDS Research and Reagent Program, National Institutes of Health (Bethesda, MD, USA). Anti-p300 (RW-128) was from Upstate (Massachusetts, USA). Anti-CDK4 (H22), anti-cyclin D3 (DSC-28), anti-RelA (C-20) and antip21 (C-19) antibodies were from Santa Cruz Biotechnologies (California, USA). Anti-actin, anti-Flag (M2) and the biotinylated anti-HA antibodies were from Sigma (St. Louis, USA). Anti-phospho T826 pRb antibody was from Abcam (Cambridge, UK). The secondary antibodies used for immunofluorescence staining were Dylight 488conjugated goat anti-mouse IgG2a, Dylight 549- or 488conjugated goat anti-rabbit IgG and Dylight 649conjugated goat anti-mouse IgG1 from Jackson ImmunoResearch (Pennsylvania, USA).

\section{Luciferase activities}

Tax-mediated transactivation of genes expression via the NF- $\kappa B$ and ATF/CREB pathway was evaluated by dual luciferase assays using of the transfected $\kappa B$-luc and HTLV-1-LTR-luc reporter constructs respectively. Rat-1 cells $\left(1 \times 10^{5}\right)$ transducted with either the control lentivirus or with the lentivirus expressing wild type Tax were transfected into 12-well plates with $500 \mathrm{ng}$ of pRL-TK-luc (Promega), used for monitoring transfection efficiency, and either $500 \mathrm{ng}$ of $\mathrm{kB}$-luc or $500 \mathrm{ng}$ of HTLV-1-LTR-luc reporter plasmids. $24 \mathrm{~h}$ after transfection, cells were lysed and subjected to luciferase assay with the dual luciferase reporter assay system (Promega) and a TD20/20 luminometer (Turner Designs) according to protocol of the manufacturer. For E2F luciferase assays, $\mathrm{CHO}$ cells were transfected with $250 \mathrm{ng}$ of p3xE2F-WT-luc and 100 ng of pRL-TK-luc reporter plasmids, and vectors expressing cyclin D3 and CDK4 (50 ng each). The effects of p21 CDK inhibitor and WT Tax or $\mathrm{K}_{346} \mathrm{R}$ or $\mathrm{K}_{346} \mathrm{Q}$ mutants on activation of the E2F-controlled promoter were assessed by cotransfection of p21 (100 ng) and Tax (600 ng) expression vectors. 


\section{Two-dimensional (2D) gel electrophoresis}

Cells were lysed in lysis buffer containing $7 \mathrm{M}$ urea, $2 \mathrm{M}$ thiourea, $40 \mathrm{mM}$ DTT, $4 \%$ (w/v) CHAPS and deacetylase, protease and phosphatase inhibitors $(0.5 \mu \mathrm{M}$ TSA and 5 mM NAA, complete EDTA-free and Phosphostop from Roche Diagnostics GmbH, Mannheim, Germany). Immunoglobulins $(0.4 \mu \mathrm{g})$ were used as internal $\mathrm{pH}$ markers and added to the sample before loading. Proteins were separated by isoelectric focusing using the Ettan IPGphor3 apparatus from GE Healthcare (Buckinghamshire, UK) and active in-gel rehydratation of pH5-8 IPG strips as described in manufacturer's protocol (BioRad, California, USA). After isoelectric focusing, the IPG strips were loaded onto 4-12\% Bis-Tris NuPAGE gel (Life technologies, Paisley, UK) for separation according to molecular mass. Methods for second dimension electrophoresis and Western Blotting have been described [47].

\section{Co-immunoprecipitation and in vitro $\mathrm{pRb}$ phosphorylation assay}

Co-immunoprecipitation and in vitro $\mathrm{pRb}$ phosphorylation assay were performed according to [58]. Briefly, cells were lysed in buffer containing $150 \mathrm{mM} \mathrm{NaCl}, 50 \mathrm{mM}$ Tris- $\mathrm{HCl} \mathrm{pH}$ 7.5, 0.5\% Nonidet P-40, $50 \mathrm{mM} \mathrm{NaF}, 1$ $\mathrm{mM}$ sodium orthovanadate, $1 \mathrm{mM} \beta$-glycerophosphate, $10 \mathrm{mM}$ DTT, protease inhibitors (complete EDTA-free, Roche Diagnostics $\mathrm{GmbH}$, Mannheim, Germany), and $10 \%$ glycerol. The homogenized cellular lysates were cleared and incubated at $4^{\circ} \mathrm{C}$ for $3 \mathrm{~h}$ with protein A sepharose 4 fast flow that had been preincubated overnight with $2 \mu \mathrm{g}$ of the antibody used for immunoprecipitation. Immunoprecipitated complexes were resuspended in kinase reaction buffer (50 mM HEPES, pH 7.5, $10 \mathrm{mM} \mathrm{KCl}$, $10 \mathrm{mM} \mathrm{MgCl}$, $2.5 \mathrm{mM}$ EGTA, $1 \mathrm{mM}$ DTT) containing $2 \mathrm{mM}$ ATP, $0.5 \mu \mathrm{g}$ of a pRb fragment (amino acids 773928) (Sigma, St. Louis, USA), $10 \mathrm{mM} \beta$-glycerophosphate, $0.1 \mathrm{mM}$ orthovanadate, $1 \mathrm{mM} \mathrm{NaF}$, protease inhibitors (complete EDTA-free, Roche Diagnostics GmbH, Mannheim, Germany), and incubated for $30 \mathrm{~min}$ at $30^{\circ} \mathrm{C}$. Immunoprecipitated complexes and kinase assays were separated on 4-12\% Bis-Tris NuPAGE gel (Life technologies, Paisley, UK) and analyzed by Western Blotting. The detection was performed using the ECL Advance Western Blotting detection kit (GE Healthcare, Buckinghamshire, UK) and quantitation of chemiluminescent signals was performed with the Chemi-Smart 5000 apparatus and Bio1D software (Vilber Lourmat, Marne-la-Vallée, France).

\section{Immunofluorescence and confocal microscopy}

Cells were grown on glass coverslips and fixed with immunohistofix (Gentaur, Kampenhout, Belgium) for $10 \mathrm{~min}$ at room temperature (RT) followed by methanol for $6 \mathrm{~min}$ at $-20^{\circ} \mathrm{C}$ and further processed as described previously [39].

\section{Additional files}

Additional file 1: Treatment of Tax expressing cells with HDAC inhibitor TSA increases Tax acetylation. 293T cells expressing Tax were treated for $18 \mathrm{~h}$ with TSA at the indicated concentrations and analyzed by Western Blotting using anti-Tax, anti-AcK ${ }_{346}$ Tax and anti-actin antibodies. The numbers under the blots represent relative quantities of each Tax species normalized to equal amount of actin.

Additional file 2: Detection of phosphorylated forms of Tax. 293T cells were transfected with a vector expressing WT Tax and metabolically labeled with ${ }^{32} \mathrm{P}$ orthophosphate. The cell extracts were separated by two-dimensional gel electrophoresis and analyzed by Western Blotting with the anti-Tax mAb and autoradiography. Quantitation of the NM (non-modified), Ac (acetylated), P (phosphorylated) and Ac/P (acetylated and phosphorylated) species on the anti-Tax immunoblot was done using Image J software.

Additional file 3: Specificity of anti-AcK ${ }_{\mathbf{3 4 6}}$ Tax. ELISA was performed by coating 96-well plates with 100 ng of either the non acetylated peptide or the acetylated peptide that was used for rabbit immunization. Serial dilutions of the anti-AcK 346 Tax antibody $(4.6 \mathrm{mg} / \mathrm{ml})$ followed by anti-rabbit-HRP were incubated for 2 hours. The substrate was incubated for $30 \mathrm{~min}$ and the reaction was stopped with $4 \mathrm{M} \mathrm{H}_{2} \mathrm{SO}_{4}$, followed by optical density measurements at $492 \mathrm{~nm}$.

\section{Competing interests}

The authors declare that they have no competing interest.

\section{Authors' contributions}

$J$, CS, MB, ASR and KC made the experiments. JL wrote the manuscript. LW, PPR and FB supervised the work and corrected the manuscript. All authors read and approved the final manuscript.

\section{Acknowledgements}

The authors warmly thank Drs. L Banks, F Dequiedt, J-M Mesnard, M Fujii, L Hengst and J-C Twizere for providing reagents and Dr. Lucy Rasmussen from Stanford University (ret.) for editorial assistance. This work was supported by grants from the Belgian Fonds de la Recherche Scientifique Médicale (FRSM), from the FNRS-Télévie, from the Internationale Brachet Stiftung, the Belgian Foundation against Cancer (2010-172 to PPR). JL and KC are FRS-FNRS/ Télévie Scientific Researchers; CS, ASR and MB were/are FRS-FNRS Postdoctoral Fellows; PPR and LW are Senior Research Associates of the FRS-FNRS.

\section{Author details}

${ }^{1}$ Institute for Microbiological Research J-M Wiame (IRMW), Laboratory of Microbiology, Université Libre de Bruxelles, 1, Avenue E. Gryson, Brussels, Belgium. ${ }^{2}$ National Fund for Scientific Research, Molecular Biology, GIGA and Gembloux Agro-Bio Tech, Université de Liège, Liège, Belgium. ${ }^{3}$ Institute of Interdisciplinary Research (IRIBHM), Université Libre de Bruxelles, Campus Erasme, Brussels, Belgium.

Received: 29 March 2013 Accepted: 18 July 2013

Published: 23 July 2013

\section{References}

1. Yoshida M, Seiki M, Yamaguchi K, Takatsuki K: Monoclonal integration of human T-cell leukemia provirus in all primary tumors of adult T-cell leukemia suggests causative role of human T-cell leukemia virus in the disease. Proc Natl Acad Sci U S A 1984, 81:2534-2537.

2. Osame M, Usuku K, Izumo S, ljichi N, Amitani H, Igata A, et al: HTLV-I associated myelopathy, a new clinical entity. Lancet 1986, 1:1031-1032.

3. Poiesz BJ, Ruscetti FW, Gazdar AF, Bunn PA, Minna JD, Gallo RC: Detection and isolation of type $C$ retrovirus particles from fresh and cultured lymphocytes of a patient with cutaneous T-cell lymphoma. Proc Natl Acad Sci U S A 1980, 77:7415-7419.

4. Hirai H, Fujisawa J, Suzuki T, Ueda K, Muramatsu M, Tsuboi A, et al: Transcriptional activator Tax of HTLV-1 binds to the NF-kappa B precursor p105. Oncogene 1992, 7:1737-1742. 
5. Petropoulos L, Lin R, Hiscott J: Human T cell leukemia virus type 1 tax protein increases NF-kappa B dimer formation and antagonizes the inhibitory activity of the I kappa B alpha regulatory protein. Virology 1996, 225:52-64.

6. Sun SC, Ballard DW: Persistent activation of NF-kappaB by the tax transforming protein of HTLV-1: hijacking cellular IkappaB kinases. Oncogene 1999, 18:6948-6958.

7. O'Mahony AM, Montano M, Van Beneden K, Chen LF, Greene WC: Human T-cell lymphotropic virus type 1 tax induction of biologically Active NF-kappaB requires IkappaB kinase-1-mediated phosphorylation of RelA/p65. J Biol Chem 2004, 279:18137-18145.

8. Harhaj EW, Harhaj NS: Mechanisms of persistent NF-kappaB activation by HTLV-I tax. IUBMB Life 2005, 57:83-91.

9. Shembade N, Harhaj NS, Yamamoto M, Akira S, Harhaj EW: The human T-cell leukemia virus type 1 Tax oncoprotein requires the ubiquitinconjugating enzyme Ubc13 for NF-kappaB activation. J Virol 2007, 81:13735-13742.

10. Xiao G, Cvijic ME, Fong A, Harhaj EW, Uhlik MT, Waterfield M, et al: Retroviral oncoprotein Tax induces processing of NF-kappaB2/p100 in T cells: evidence for the involvement of IKKalpha. EMBO J 2001, 20:6805-6815

11. Higuchi M, Tsubata C, Kondo R, Yoshida S, Takahashi M, Oie M, et al: Cooperation of NF-kappaB2/p100 activation and the PDZ domain binding motif signal in human T-cell leukemia virus type 1 (HTLV-1) Tax1 but not HTLV-2 Tax2 is crucial for interleukin-2-independent growth transformation of a T-cell line. J Virol 2007, 81:11900-11907.

12. Fu J, Qu Z, Yan P, Ishikawa C, Aqeilan RI, Rabson AB, et al: The tumor suppressor gene WWOX links the canonical and noncanonical NFkappaB pathways in HTLV-I Tax-mediated tumorigenesis. Blood 2011, 117:1652-1661.

13. Shoji T, Higuchi M, Kondo R, Takahashi M, Oie M, Tanaka Y, et al: Identification of a novel motif responsible for the distinctive transforming activity of human T-cell leukemia virus (HTLV) type 1 Tax 1 protein from HTLV-2 Tax2. Retrovirology 2009, 6:83.

14. Suzuki T, Hirai H, Fujisawa J, Fujita T, Yoshida M: A trans-activator Tax of human T-cell leukemia virus type 1 binds to NF-kappa B p50 and serum response factor (SRF) and associates with enhancer DNAs of the NF-kappa B site and CArG box. Oncogene 1993, 8:2391-2397.

15. Fujii M, Tsuchiya H, Chuhjo T, Minamino T, Miyamoto K, Seiki M: Serum response factor has functional roles both in indirect binding to the CArG box and in the transcriptional activation function of human T-cell leukemia virus type I Tax. J Virol 1994, 68:7275-7283.

16. Winter HY, Marriott SJ: Human T-cell leukemia virus type 1 Tax enhances serum response factor DNA binding and alters site selection. J Virol 2007, 81:6089-6098

17. Iwai K, Mori N, Oie M, Yamamoto N, Fujii M: Human T-cell leukemia virus type 1 tax protein activates transcription through AP-1 site by inducing DNA binding activity in T cells. Virology 2001, 279:38-46.

18. Hall WW, Fujii M: Deregulation of cell-signaling pathways in HTLV-1 infection. Oncogene 2005, 24:5965-5975.

19. Kinjo T, Ham-Terhune J, Peloponese JM Jr, Jeang KT: Induction of reactive oxygen species by human T-cell leukemia virus type 1 tax correlates with DNA damage and expression of cellular senescence marker. J Virol 2010, 84:5431-5437.

20. Boxus M, Twizere JC, Legros S, Kettmann R, Willems L: Interaction of HTLV1 Tax with minichromosome maintenance proteins accelerates the replication timing program. Blood 2012, 119:151-160.

21. Haoudi A, Daniels RC, Wong E, Kupfer G, Semmes OJ: Human T-cell leukemia virus-I tax oncoprotein functionally targets a subnuclear complex involved in cellular DNA damage-response. J Biol Chem 2003 278:37736-37744.

22. Chandhasin C, Ducu RI, Berkovich E, Kastan MB, Marriott SJ: Human T-cell leukemia virus type 1 tax attenuates the ATM-mediated cellular DNA damage response. J Virol 2008, 82:6952-6961.

23. Jeong SJ, Pise-Masison CA, Radonovich MF, Park HU, Brady JN: A nove NF-kappaB pathway involving IKKbeta and p65/RelA Ser-536 phosphorylation results in p53 Inhibition in the absence of NF-kappaB transcriptional activity. J Biol Chem 2005, 280:10326-10332.

24. Gupta SK, Guo X, Durkin SS, Fryrear KF, Ward MD, Semmes OJ: Human T-cell leukemia virus type 1 Tax oncoprotein prevents DNA damageinduced chromatin egress of hyperphosphorylated Chk2. J Biol Chem 2007, 282:29431-29440.
25. Belgnaoui SM, Fryrear KA, Nyalwidhe JO, Guo X, Semmes OJ: The viral oncoprotein tax sequesters DNA damage response factors by tethering MDC1 to chromatin. J Biol Chem 2010, 285:32897-32905

26. Neuveut C, Low KG, Maldarelli F, Schmitt I, Majone F, Grassmann R, et al: Human T-cell leukemia virus type 1 Tax and cell cycle progression: role of cyclin D-cdk and p110Rb. Mol Cell Biol 1998, 18:3620-3632.

27. Fraedrich K, Muller B, Grassmann R: The HTLV-1 Tax protein binding domain of cyclin-dependent kinase 4 (CDK4) includes the regulatory PSTAIRE helix. Retrovirology 2005, 2:54.

28. Haller K, Wu Y, Derow E, Schmitt I, Jeang KT, Grassmann R: Physical interaction of human T-cell leukemia virus type 1 Tax with cyclindependent kinase 4 stimulates the phosphorylation of retinoblastoma protein. Mol Cell Biol 2002, 22:3327-3338.

29. Li J, Li H, Tsai MD: Direct binding of the N-terminus of HTLV-1 tax oncoprotein to cyclin-dependent kinase 4 is a dominant path to stimulate the kinase activity. Biochemistry 2003, 42:6921-6928.

30. Schmitt I, Rosin O, Rohwer P, Gossen M, Grassmann R: Stimulation of cyclin-dependent kinase activity and G1- to S-phase transition in human lymphocytes by the human T-cell leukemia/lymphotropic virus type 1 Tax protein. J Virol 1998, 72:633-640.

31. Rousset $R$, Fabre $S$, Desbois $C$, Bantignies $F$, Jalinot $P$ : The C-terminus of the HTLV-1 Tax oncoprotein mediates interaction with the PDZ domain of cellular proteins. Oncogene 1998, 16:643-654.

32. Suzuki T, Ohsugi Y, Uchida-Toita M, Akiyama T, Yoshida M: Tax oncoprotein of HTLV-1 binds to the human homologue of Drosophila discs large tumor suppressor protein, hDLG, and perturbs its function in cell growth control. Oncogene 1999, 18:5967-5972.

33. Hirata A, Higuchi M, Niinuma A, Ohashi M, Fukushi M, Oie M, et al: PDZ domain-binding motif of human T-cell leukemia virus type 1 Tax oncoprotein augments the transforming activity in a rat fibroblast cell line. Virology 2004, 318:327-336.

34. Xie L, Yamamoto B, Haoudi A, Semmes OJ, Green PL: PDZ binding motif of HTLV-1 Tax promotes virus-mediated T-cell proliferation in vitro and persistence in vivo. Blood 2006, 107:1980-1988.

35. Arpin-Andre C, Mesnard JM: The PDZ domain-binding motif of the human T cell leukemia virus type 1 tax protein induces mislocalization of the tumor suppressor hScrib in T cells. J Biol Chem 2007, 282:33132-33141.

36. Makokha GN, Takahashi M, Higuchi M, Saito S, Tanaka Y, Fujii M: Human T-cell leukemia virus type 1 Tax protein interacts with and mislocalizes the PDZ domain protein MAGI-1. Cancer Sci 2013, 104:313-320.

37. Zhao T, Matsuoka M: HBZ and its roles in HTLV-1 oncogenesis. Front Microbiol 2012, 3:247.

38. Bex F, Murphy K, Wattiez R, Burny A, Gaynor RB: Phosphorylation of the human T-cell leukemia virus type 1 transactivator tax on adjacent serine residues is critical for tax activation. J Virol 1999, 73:738-745.

39. Lamsoul I, Lodewick J, Lebrun S, Brasseur R, Burny A, Gaynor RB, et al: Exclusive ubiquitination and sumoylation on overlapping lysine residues mediate NF-kappaB activation by the human T-cell leukemia virus tax oncoprotein. Mol Cell Biol 2005, 25:10391-10406.

40. Nasr R, Chiari E, El Sabban M, Mahieux R, Kfoury Y, Abdulhay M, et al: Tax ubiquitylation and sumoylation control critical cytoplasmic and nuclear steps of NF-kappa B activation. Blood 2006, 107:4021-4029.

41. Fryrear KA, Guo X, Kerscher O, Semmes OJ: The Sumo-targeted ubiquitin ligase RNF4 regulates the localization and function of the HTLV-1 oncoprotein Tax. Blood 2012, 119:1173-1181.

42. Durkin SS, Ward MD, Fryrear KA, Semmes OJ: Site-specific phosphorylation differentiates active from inactive forms of the human T-cell leukemia virus type 1 Tax oncoprotein. J Biol Chem 2006, 281:31705-31712.

43. Lodewick J, Lamsoul I, Bex F: Move or die: the fate of the Tax oncoprotein of HTLV-1. Viruses 2011, 3:829-857.

44. Bonnet A, Randrianarison-Huetz V, Nzounza P, Nedelec M, Chazal M, Waast $L$, et al: Low nuclear body formation and tax SUMOylation do not prevent NF-kappaB promoter activation. Retrovirology 2012, 9:77.

45. Xiao G: NF-kappaB activation: Tax sumoylation is out, but what about Tax ubiquitination? Retrovirology 2012, 9:78.

46. Zane $L$, Jeang $K T$ : The importance of ubiquitination and sumoylation on the transforming activity of HTLV Tax-1 and Tax-2. Retrovirology 2012, 9:103.

47. Lodewick J, Lamsoul I, Polania A, Lebrun S, Burny A, Ratner L, et al: Acetylation of the human T-cell leukemia virus type 1 Tax oncoprotein by $\mathrm{p} 300$ promotes activation of the NF-kappa B pathway. Virology 2009, 386:68-78. 
48. Semmes OJ, Majone F, Cantemir C, Turchetto L, Hjelle B, Jeang KT: HTLV-I and HTLV-II Tax: differences in induction of micronuclei in cells and transcriptional activation of viral LTRs. Virology 1996, 217:373-379.

49. Majone $F$, Luisetto $R$, Zamboni $D$, Iwanaga $Y$, Jeang $K T$ : Ku protein as a potential human T-cell leukemia virus type 1 (HTLV-1) Tax target in clastogenic chromosomal instability of mammalian cells. Retrovirology 2005, 2:45

50. Bex F, Yin MJ, Burny A, Gaynor RB: Differential transcriptional activation by human T-cell leukemia virus type 1 Tax mutants is mediated by distinct interactions with CREB binding protein and p300. Mol Cell Biol 1998 18:2392-2405

51. Li M, Luo J, Brooks CL, Gu W: Acetylation of p53 inhibits its ubiquitination by Mdm2. J Biol Chem 2002, 277:50607-50611.

52. Yamaoka S, Inoue H, Sakurai M, Sugiyama T, Hazama M, Yamada T, et al: Constitutive activation of NF-kappa B is essential for transformation of rat fibroblasts by the human T-cell leukemia virus type I Tax protein. EMBO J 1996, 15:873-887.

53. Sun SC, Yamaoka S: Activation of NF-kappaB by HTLV-I and implications for cell transformation. Oncogene 2005, 24:5952-5964.

54. Bockstaele L, Coulonval K, Kooken H, Paternot S, Roger PP: Regulation of CDK4. Cell Div 2006, 1:25.

55. Cheng M, Olivier P, Diehl JA, Fero M, Roussel MF, Roberts JM, et al: The p21 (Cip1) and p27(Kip1) CDK 'inhibitors' are essential activators of cyclin D-dependent kinases in murine fibroblasts. EMBO J 1999, 18:1571-1583.

56. Sherr CJ, Roberts JM: CDK inhibitors: positive and negative regulators of G1-phase progression. Genes Dev 1999, 13:1501-1512.

57. LaBaer J, Garrett MD, Stevenson LF, Slingerland JM, Sandhu C, Chou HS, et al: New functional activities for the p21 family of CDK inhibitors. Genes Dev 1997, 11:847-862.

58. Bockstaele L, Kooken H, Libert F, Paternot S, Dumont JE, de Launoit Y, et al: Regulated activating Thr172 phosphorylation of cyclin-dependent kinase 4(CDK4): its relationship with cyclins and CDK "inhibitors". Mol Cell Biol 2006, 26:5070-5085.

59. Hay RT: SUMO: a history of modification. Mol Cell 2005, 18:1-12.

60. Chen J, Saha P, Kornbluth S, Dynlacht BD, Dutta A: Cyclin-binding motifs are essential for the function of p21CIP1. Mol Cell Biol 1996, 16:4673-4682.

61. Chowdhury $\mathrm{H}$, Farhadi A, Wang XF, Robb ML, Birx DL, Kim JH: Human T-cell leukemia virus type 1 Tax activates cyclin-dependent kinase inhibitor p21/Waf1/Cip1 expression through a p53-independent mechanism: Inhibition of cdk2. Int J Cancer 2003, 107:603-611.

62. de La FC, Deng L, Santiago F, Arce L, Wang L, Kashanchi F: Gene expression array of HTLV type 1-infected T cells: Up-regulation of transcription factors and cell cycle genes. AIDS Res Hum Retroviruses 2000, 16:1695-1700.

63. Starostina NG, Kipreos ET: Multiple degradation pathways regulate versatile CIP/KIP CDK inhibitors. Trends Cell Biol 2012, 22:33-41.

64. Iwanaga R, Ozono E, Fujisawa J, Ikeda MA, Okamura N, Huang Y, et al: Activation of the cyclin D2 and cdk6 genes through NF-kappaB is critical for cell-cycle progression induced by HTLV-I Tax. Oncogene 2008, 27:5635-5642

65. Kehn K, Deng L, de La FC, Strouss K, Wu K, Maddukuri A, et al: The role of cyclin D2 and p21/waf1 in human T-cell leukemia virus type 1 infected cells. Retrovirology 2004, 1:6.

66. Majone F, Semmes OJ, Jeang KT: Induction of micronuclei by HTLV-I Tax: a cellular assay for function. Virology 1993, 193:456-459.

67. Bertazzoni U, Turci M, Avesani F, di Gennaro G, Bidoia C, Romanelli MG: Intracellular localization and cellular factors interaction of HTLV-1 and HTLV-2 Tax proteins: similarities and functional differences. Viruses 2011, 3:541-560

68. Tripp A, Banerjee P, Sieburg M, Planelles V, Li F, Feuer G: Induction of cell cycle arrest by human T-cell lymphotropic virus type 1 Tax in hematopoietic progenitor (CD34+) cells: modulation of p21cip1/waf1 and p27kip1 expression. J Virol 2005, 79:14069-14078.

69. Zimmerman B, Sargeant A, Landes K, Fernandez SA, Chen CS, Lairmore MD: Efficacy of novel histone deacetylase inhibitor, AR42, in a mouse model of, human T-lymphotropic virus type 1 adult T cell lymphoma. Leuk Res 2011, 35:1491-1497.

70. Olindo S, Belrose G, Gillet N, Rodriguez S, Boxus M, Verlaeten O, et al: Safety of long-term treatment of HAM/TSP patients with valproic acid. Blood 2011, 118:6306-6309.
71. Nagata K, Ohtani K, Nakamura M, Sugamura K: Activation of endogenous c-fos proto-oncogene expression by human T-cell leukemia virus type Iencoded p40tax protein in the human T-cell line, Jurkat. J Virol 1989, 63:3220-3226.

72. Gardiol D, Galizzi S, Banks L: Mutational analysis of the discs large tumour suppressor identifies domains responsible for human papillomavirus type 18 E6-mediated degradation. J Gen Virol 2002, 83:283-289.

73. Dequiedt F, Van Lint J, Lecomte E, Van DV, Seufferlein T, Vandenheede JR, et al: Phosphorylation of histone deacetylase 7 by protein kinase $D$ mediates T cell receptor-induced Nur77 expression and apoptosis. J Exp Med 2005, 201:793-804.

74. Lemasson I, Thebault S, Sardet C, Devaux C, Mesnard JM: Activation of E2F-mediated transcription by human T-cell leukemia virus type I Tax protein in a p16 (INK4A)-negative T-cell line. J Biol Chem 1998, 273:23598-23604.

doi:10.1186/1742-4690-10-75

Cite this article as: Lodewick et al: Acetylation at lysine 346 controls the transforming activity of the HTLV-1 Tax oncoprotein in the Rat-1 fibroblast model. Retrovirology 2013 10:75.

\section{Submit your next manuscript to BioMed Central and take full advantage of:}

- Convenient online submission

- Thorough peer review

- No space constraints or color figure charges

- Immediate publication on acceptance

- Inclusion in PubMed, CAS, Scopus and Google Scholar

- Research which is freely available for redistribution 